\title{
A Tale of Two Londons: Locating Shakespeare and Dickens in 2012
}

by Peter Kirwan and Charlotte Mathieson

\section{Introduction}

In 1847, the sale of a key piece of Shakespearean heritage to the American showman P.T. Barnum, who wished to purchase, disassemble and ship the house on Henley Street known as Shakespeare's birthplace to the United States, was halted. One of the key players among the committee of fundraisers who found the $£ 3,000$ necessary to keep the house in its original location was Charles Dickens, already by this point a celebrated novelist inextricably connected to the physical and cultural hub of London. Dickens had experienced first-hand the value of the Shakespeare birthplace on a visit to the region in 1838, writing in his letters of how 'we sat down in the room where Shakespeare was born, and left our autographs and read those of other people and so forth.' ${ }^{1}$ Although his fiction jests at those who are over-inspired by an almost spiritual investment in Shakespeare's birthplace, Dickens's role in saving the house from international export is nonetheless indicative of the increasing cultural value ascribed to literary places as sites of national significance throughout the nineteenth century as authors became solidified as national symbols through the rendering of literary locations as tourist destinations - a practice that would later render 'Dickens's London' a key site in the literary tourist landscape.

Dickens's involvement in the purchase of the Shakespeare birthplace represents a meeting-point of Britain's two most prominent writers which serves to underscore the centrality of place in the creation and performance of Britain's national literary heritage. In 2012, the use of literary places in a wider project of national identity formation came to the fore in the

\footnotetext{
${ }^{1}$ Charles Dickens, The Letters of Charles Dickens, ed. by Mamie Dickens and Georgina Hogarth (London: Macmillan, 1893), p. 17.
} 
concurrent celebrations of Dickens and Shakespeare that formed part of the Cultural Olympiad: the World Shakespeare Festival (introduced elsewhere in this volume) and Dickens 2012, 'an international celebration of the life and work of Charles Dickens to mark the bicentenary of his birth' that included hundreds of historical, literary, theatrical, cinematic, architectural, educational and heritage events throughout the year. ${ }^{2}$ Both Festivals were international in scope, but it was London that formed the centre-point of these events. Neither Dickens nor Shakespeare were born in London but both are inextricably associated with the city through their careers and, as the city's most famous literary exports, both were employed prominently within the context of London's 2012 celebrations that created a national legacy, and positioned that legacy on the global stage.

Yet the role played by these two authors in shaping London's cultural capital was marked by a demonstrable tension in the global politics that underscored the Festivals. Reflecting the breadth and diversity of both authors' works and cultural afterlives, both Festivals appropriately encompassed a significant international constituency, the World Shakespeare Festival taking an explicitly global focus while Dickens 2012 incorporated events from around the world. Yet despite this global reach, both Festivals continued to assert the prominence of London as cultural centre and privileged this space as the location of authorial meaning; an investment that carried particular weight in a year - that of the Queen's Diamond Jubilee - already preoccupied with the cultural construction of 'Britishness'. In this chapter, we interrogate the local and global resonances of Shakespeare and Dickens in the Olympic year and question the assumptions and

\footnotetext{
2 'About Dickens 2012', Dickens 2012 <http://www.dickens2012.org/about-dickens-2012>
} [accessed 1 October 2013]. 
politics of literary place - in this context London - governing the cultural memory of these authors.

\section{London: E20, GB}

In March 2011, as the Olympic Park in the regenerated Stratford area of East London began to take shape, a new postcode was created within the E15 area: E20, previously only a fictional postcode used in the British soap EastEnders and its Internet spin-off E20. ${ }^{3}$ The consolidation of a newly defined space within London emphasised the importance of this relatively small geographical area on the edges of the city as the place which would be responsible for presenting London to the world. Furthermore, the creation of E20 highlighted the centrality of place as a historically significant constituent in the formation and consolidation of national identity: as Ian Baucom writes, Englishness in particular 'has consistently been defined through appeals to the identity-endowing properties of place $[\ldots]$ generally understood to reside within some type of imaginary, abstract, or actual locale, and to mark itself upon that locale's familiars. ${ }^{4}$ In 2012 , traces of celebration were inscribed throughout London, investing the city with markers of its national history and heritage: the Queen's Diamond Jubilee in June 2012 gave rise to a multitude of Union Jack flags throughout the city, a 100 metre-wide picture of the Royal Family towered over the banks of the Thames, and the Thames Diamond Jubilee Pageant that marked the culmination of the weekend reinstated (albeit fleetingly) the river, so central in the city and

\footnotetext{
3 'Olympic Park to Share EastEnders' Walford E20 postcode', BBC News, 19 March 2011 〈http://www.bbc.co.uk/news/uk-england-london-12789694> [accessed 1 October 2013]. ${ }^{4}$ Ian Baucom, Out of Place: Englishness, Empire and the Locations of Identity (Princeton: Princeton University Press, 1999), p. 4.
} 
nation's history, as a prominent and meaningful site (for other reflections on the 'spectacular city', see Stuart Hampton-Reeves in this volume).

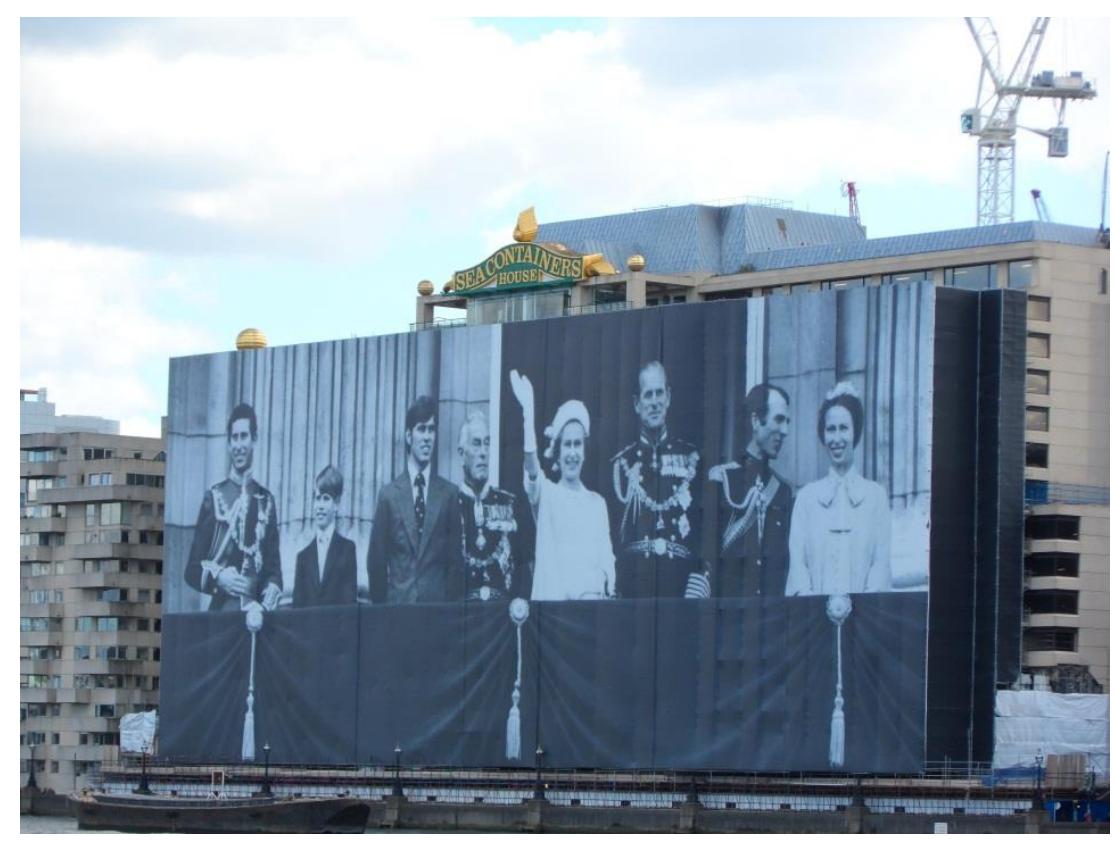

Fig. 1: image of the Royal Family at the Queen's Silver Jubilee of 1977 on the River Thames

The creation of E20 consolidated these resonances into a specific locale, forging a place that became newly assimilated into Britain's national geography. The cultural rejuvenation of Stratford worked, to borrow Susan Bennett's description of the revitalisation of the South Bank, 'to show the city to itself and to inspire its occupants and its visitors to become actors in a reconfigured landscape, to forge emotional connections to a neighborhood not so long ago more 
dead than alive'. 5 Significantly, what the reconfigured landscape of E20 represented and inspired was a new vision of the city, and of Britain: it created a place where new modes of national identity formation befitting the contemporary moment could be performed. 'Britishness' was continually reimagined throughout 2012: if the monarchical celebrations of the Jubilee met with ambivalence from those disdainful of the pomp and circumstance surrounding this problematised aspect of Britain's history, Danny Boyle's 'Isles of Wonder' Ceremony that launched the Olympic Games was widely and hyperbolically lauded as a defining moment of a new national culture. ${ }^{6}$ Demonstrating an inclusive, left-wing politics that shied away from vindications of an imperial past and instead celebrated Britain for its idiosyncrasies, national social institutions and diverse cultural spectrum, 'Isles of Wonder', as Jonathan Freedland wrote, 'had barely finished before it had become a byword for a new approach, not only to British culture but to Britishness itself', providing the nation 'with a new, unfamiliarly positive view of itself.'

The nation's history and (particularly literary) culture was central to the Ceremony, through which the performance created its own form of cultural canonisation - at times inevitable, but diverse and often unexpected. The most high-profile manifestation of this was the

${ }^{5}$ Susan Bennett, 'Universal Experience: The City as Tourist Stage', in The Cambridge Companion to Performance Studies, ed. by Tracy C. Davis (Cambridge: Cambridge University Press, 2008), pp. 76-90 (p. 84).

6 'Isles of Wonder', dir. Danny Boyle, performed on 27 July 2012 at the Olympic Stadium, London.

${ }^{7}$ Jonathan Freedland, 'Danny Boyle: Champion of the people', Guardian, 9 March 2013, <http://www.guardian.co.uk/film/2013/mar/09/danny-boyle-queen-olympics-

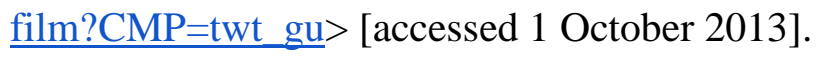


deployment of Shakespeare in the Opening Ceremony, where the Northern Irish actor Kenneth Branagh, playing Isambard Kingdom Brunel, recited Caliban's speech from The Tempest. Little has been said so far about the visual context in which this aural tribute to Shakespeare was performed. Erin Sullivan's description of the appearance of the great Shakespearean as the great Victorian is illuminating:

[...] a nineteenth-century stagecoach approached a recreation of England's grassy Glastonbury Tor [...] From the stagecoach emerged Sir Kenneth Branagh, dressed as a Victorian industrialist (Isambard Kingdom Brunel, to be exact), looking excitedly, expectantly and triumphantly at the expansive bucolic stage set before him. ${ }^{8}$

Although this was not the start of the Ceremony, Branagh's Brunel acted as the catalyst for the initiation of catastrophic change, the tearing apart of the pastoral set and the initiation of 'modern' Britain, out of which were forged the Olympic rings. The visual aesthetic of the moment drew on recognisably Victorian tropes, with stagecoaches, smokestacks and top hats presenting an image of industrial upheaval.

In this, the Ceremony demonstrably resonated with the 1951 Festival of Britain, which took place as Britain attempted to heal its post-war wounds and consolidate its identity following a particularly scarring period of international engagement: the Festival, as Herbert Morrison

\footnotetext{
${ }^{8}$ Erin Sullivan, 'Olympic Performance in the Year of Shakespeare', in A Year of Shakespeare: Re-living the World Shakespeare Festival, ed. by Paul Edmondson, Paul Prescott and Erin Sullivan (London: Bloomsbury, 2013), pp. 3-11 (p. 3).
} 
wrote, was 'the British showing themselves to themselves - and the world. ${ }^{9}$ Key to this was a strategic deployment of Shakespeare as 'an unarguable figure of achievement, recognized nationally and internationally', who could contribute to forming 'a new de-imperialized history to drive Britain into the future'. ${ }^{10}$ So too was the use of a Victorian aesthetic important, with a stagecoach featuring prominently in the Festival literature and a Dickensian feast forming one of the many events. ${ }^{11}$ The Festival's instatement of the Victorians as an integral feature was appropriate in its marking the centenary of the Great Exhibition of 1851, and it also initiated the resurgence of interest in the Victorians that has continued to develop into the neo-Victorian fascination of recent years: as Ann Heilmann and Mark Llewellyn note, the 'very instability and insecurity relating to the recent memories of the twentieth century, from the Second World War through to a post-9/11 landscape' lies beneath this 'reassuringly nostalgic attraction to the nineteenth century' demonstrated in the Festival of Britain, and again visible in $2012 .^{12}$

\footnotetext{
${ }^{9}$ Quote by Herbert Morrison in 'Festival of Britain 1951', Exploring $20^{\text {th }}$ Century London <http://www.20thcenturylondon.org.uk/festival-britain-1951> [accessed 1 October 2013].

${ }^{10}$ Stuart Hampton-Reeves, 'Shakespeare, Henry VI and the Festival of Britain', in A Companion to Shakespeare and Performance, ed. by Barbara Hodgdon and W. B. Worthen (Oxford:
}

Blackwell, 2005) pp. 285-296 (p. 295).

${ }^{11}$ See 'Festival of Britain', Museum of London <http://collections.museumoflondon.org.uk/Online/group.aspx?g=group-18135> [accessed 1 October 2013].

${ }^{12}$ Ann Heilmann and Mark Llewellyn, Neo-Victorianism: The Victorians in the Twenty-First Century, 1999-2009 (Basingstoke: Palgrave Macmillan, 2010), p. 225-6. 


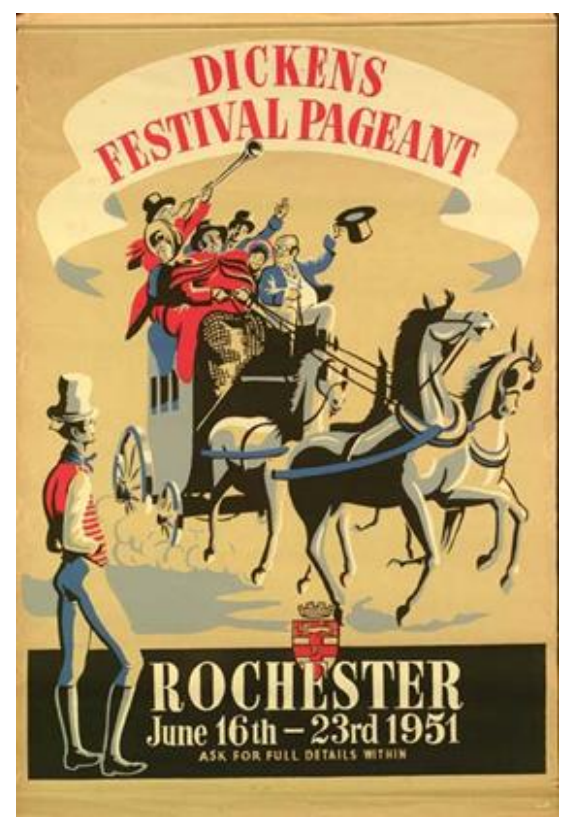

Fig. 2: Festival of Britain poster ${ }^{13}$

With the great number of Dickensian celebrations of 2012, this was arguably the year of 'neo-Victorianism par excellence', ${ }^{14}$ and it was thus fitting to see Victorian symbols take visual prominence in the aesthetics of the Opening Ceremony. Yet amidst this spectacle, Dickens himself was nowhere to be seen, his presence and texts curiously absent from the stage which instead saw a turn to Shakespeare's words spoken through the figure of Brunel. Again, though, this was in some respects a suitably neo-Victorian moment: it was, after all, the Victorians who solidified Shakespeare's status as national symbol through the consolidation of Bardolatry and

\footnotetext{
13 'Festival of Britain', Museum of London <http://collections.museumoflondon.org.uk/Online/group.aspx?g=group-18135> [accessed 1
} October 2013].

${ }^{14}$ Charlotte Boyce and Elodie Rousselot, 'The Other Dickens: Neo-Victorian Appropriation and Adaptation', Neo-Victorian Studies, 5.2 (2012), 1-11 (p. 2). 
the founding of Shakespeare societies in the context of a simultaneous strengthening of national cultural identity. ${ }^{15}$ The use of Shakespeare within a Victorian aesthetic was thus representative of, and resonant with, the Victorians' own acts of cultural formulation: in this setting Shakespeare's voice emerged, not from the collaborative and chaotic milieu of a representation of Elizabethan or Jacobean London, but from the organised and powerfully authoritarian society inculcated by a great Victorian.

In the Closing Ceremony of the Games, performed on 12th August 2012, Shakespeare and Dickens again came into contact as prominent among the quotations disguised as newspaper cuttings that decorated the stage. ${ }^{16}$ This too is perhaps also a Victorian feature. Gary Taylor argues that

Nineteenth-century Britain realized, more clearly than any previous society, that goods can be manufactured, and information can be processed, more efficiently when broken down into components. Shakespeare's writings were accordingly broken down into so many systematically arranged components of word usage, grammatical usage, metrical usage. Sometimes the books themselves were literally broken down into fragments; some

\footnotetext{
${ }^{15}$ Howard Felperin, 'Bardolatry Then and Now', in The Appropriation of Shakespeare: PostRenaissance Reconstructions of the Works and the Myth (Hemel Hempstead: Harvester Wheatsheaf, 1991), pp. 129-44 (pp. 131-33).

${ }^{16}$ As well as quotes from Hamlet, Richard III and The Tempest and the opening lines of A Tale of Two Cities, the stage featured lines by Samuel Johnson, John Keats, Lord Byron, T.S. Eliot and John Osborne.
} 
of the early material collected for the New English Dictionary consisted of passages torn out of rare sixteenth-century books and pasted onto slips. ${ }^{17}$

The practice of excerption and quotation is, inevitably, a nostalgic process, a process that draws on memory and recognition for its effects. Margreta de Grazia points out that one of the most enduring compilations of Shakespearean quotations, William Dodd's 1752 Beauties of Shakespear, appeared in the same period as the 1769 Shakespeare Jubilee in Stratford-uponAvon, 'the event that is often taken to mark the beginning of Shakespeare bardolatry' ${ }^{18}$ Tied into the 'new longing for writing in Shakespeare's own person [that] emerged in the later eighteenth century', ${ }^{19}$ de Grazia's observation links moments of anniversary with strategies of remembrance and appropriation that resonate usefully with an Olympic year in which Shakespeare, Dickens, Brunel and Churchill were all evoked bodily and in quotation (all, not coincidentally, entrants in the 100 Greatest Britons poll conducted by the BBC in 2002). ${ }^{20}$ Nostalgia and quotation militate against unified interpretation, however: 'The disruptive intertextual effect of citation enfolded within performance can summon up for individual spectators independent and unpredictable

${ }^{17}$ Gary Taylor, Reinventing Shakespeare (New York: Weidenfeld \& Nicolson, 1989), p. 193.

${ }^{18}$ Margreta de Grazia, 'Shakespeare in Quotation Marks', in The Appropriation of Shakespeare, ed. by Jean I. Marsden (Hemel Hempstead: Harvester Wheatsheaf, 1991), pp. 57-71 (p. 61). ${ }^{19}$ Ibid., p. 57.

${ }^{20}$ For the 2002 poll, see 'BBC Reveals 100 Great British Heroes', 22 August 2002, <http://news.bbc.co.uk/1/hi/entertainment/tv_and_radio/2208532.stm $>$ [accessed 1 October 2013]. 
memories of past performances and past texts', as Margaret Jane Kidnie notes. ${ }^{21}$ As commentators on Twitter debated the appropriateness of Caliban's words, it became clear that the borrowing of the author did not necessarily lead to a unified national moment of collective remembrance. ${ }^{22}$ Internationally, this was even less the case, as some American commentators wondered what Abraham Lincoln was doing in this green English field. ${ }^{23}$

What took place at E20 was an attempt to define and perform an iconic representation of the nation in a specifically located place, aligning historical figures with such local-born celebrities as Dizzee Rascal and David Beckham. Yet we can and should question the extent to which the emotional connections to a city are, indeed, grounded in the local. At the Opening Ceremony, Branagh's Brunel spoke Caliban's 'Be not afeard' speech while presiding over Glastonbury Tor, while nationally significant songs were sung by children's choirs from all around the British Isles. At the Closing Ceremony, on the other hand, Timothy Spall offered a pastiche of Branagh's performance, addressing the audience from the top of Big Ben in a microcosmic London, situated in the centre of the same stadium in an event that insisted on a metropolitan rather than national narrative. The shift from Britain to London between the two

${ }^{21}$ Margaret Jane Kidnie, 'Citing Shakespeare', in Shakespeare, Memory and Performance, ed. by Peter Holland (Cambridge: Cambridge University Press, 2006), pp. 117-32 (p. 132).

${ }^{22}$ See the Storify page 'Shakespeare and the 2012 Olympics Opening Ceremony' compiled by 'shakesinstitute' at <http://storify.com/shakesinstitute/shakespeare-and-the-2012-olympicsopening-ceremony> [accessed 1 October 2013].

${ }^{23}$ See Maria Vultaggio, 'Kenneth Branagh at 2012 Olympic Opening Ceremony', International Business Times 27 July 2012. <http://www.ibtimes.com/kenneth-branagh-2012-olympicopening-ceremony-was-branagh-dressed-abe-lincoln-734180> [accessed 1 October 2013]. 
ceremonies bespoke the anxiety felt about the role of the Olympics in juxtaposing a city's identity and a nation's, particularly given that one of that nation's constituent members, Scotland, would soon be undergoing a referendum about its continued membership. The Shakespeare and Dickens Festivals further iterated this tension between city and nation and, through their insistence on the location of authors, served to suggest a renewed statement of the prevalent pull towards London, as the next sections explore.

\section{Locating Dickens in the Bicentenary Year}

Running throughout the year, but focused particularly around the bicentenary itself on $7^{\text {th }}$ February, Dickens 2012 was emphatically marketed as an 'international' celebration, incorporating global partners to develop projects specific to individual countries, and utilising digital technologies to connect international audiences in pan-global activities. ${ }^{24}$ At the same time, a frequent return to 'local Dickens' was suggestive of a demonstrable impulse to (literally) locate Dickens in the spaces of national culture. To signal the contrasting forces that situated Dickens as local and/or global writer is not to suggest that these elements were in direct competition with one another: Dickens 2012 operated across a broad cultural spectrum that enabled a multitude of perspectives on his life and works to come into play. Yet at the same time,

${ }^{24}$ For the full list of global projects see Dickens $2012<$ http://www.dickens2012.org > [accessed 1 October 2013]; and the British Council 'Dickens 2012’ pages <http://literature.britishcouncil.org/projects/2011/dickens-2012> [accessed 1 October 2013]. On the academic contexts and interpretations of 'global Dickens', see Regenia Gagnier, 'The Global Circulation of Charles Dickens's Novels', Literature Compass, 10.1 (2013) <http://onlinelibrary.wiley.com/doi/10.1111/lic3.12021/abstract> [accessed 1 October 2013]. 
the London activities of Dickens 2012 opened up an indicative set of questions about the cultural placing of 'national' authors and the ways in which national identities are enacted and performed through cultural celebrations.

'Local Dickens' was a prominent theme throughout 2012, taking multiple forms in various celebratory events and activities. An exhibition at the Museum of London aimed to 'evok[e] the atmosphere of the streets of Victorian London and the river Thames' allowing visitors to 'follow in Dickens' footsteps and be taken on a memorable and haunting journey', while Southwark's Cuming Museum aimed to 'uncover the places, people and living conditions' of Dickens's time in the area. ${ }^{25}$ Numerous walking tours traversed 'Dickens's London', whether by guided group tours or downloadable podcast recordings; ${ }^{26}$ and interactive maps plotted out

25 'A tale of one man and his city', Museum of London, 7 December 2011 <http://www.museumoflondon.org.uk/corporate/press-media/press-releases/dickens-andlondon/> [accessed 1 October 2013]; 'Fact into Fiction', Southwark Cuming museum <http://www.southwark.gov.uk/news/article/1005/explore_southwarks_charles_dickens_exhibiti on_this_half_term> $>$ [accessed 1 October 2013].

${ }^{26}$ See for example the Guardian's series of Dickens audio walks, which consisted of podcasts and mapped walking tours around London and neighbouring locations, 'The Guardian Dickens Audio Walk: Heart of the City', Guardian <http://www.guardian.co.uk/books/interactive/2012/jan/02/dickens-walk-heart-of-the-city> [accessed 1 October 2013]; Charles Dickens London 〈http://www.charlesdickenslondon.net> [accessed 1 October 2013]; 'Tour of Dickens’s London locations', Dickens 2012 <http://www.dickens2012.org/event/tour-dickens-london-locations-sandra-shevey $>$ [accessed 1 October 2013] and 'Tour of Dickens's Film Locations', Dickens 2012 
the places of Dickens's novels, whilst mobile apps such as 'Dickens: Dark London' promised to take the user on 'a journey through the darker side of Charles Dickens' London'. ${ }^{27}$ Films such as the resources produced by the British Council explored 'the relationship between the writer and the city he lived in'. ${ }^{28}$

It was of little surprise that in a bicentenary year emphasis should be placed on the life, times and locations of Dickens, or that London in particular should highlight Dickens's city roots: the appeal of 'Dickens's London' has a strong tradition both in academic criticism and in popular culture. Literary tourism - 'the interconnected practices of visiting and marketing sites associated with writers and their work', as Nicola Watson defines $i^{29}$ - has a long history in reference to Dickens: Dickens-themed cycle and walking routes became a popular form of leisure pursuit as early as the 1880s, and the places associated with Dickens's life and works have subsequently generated a variety of forms of tourism that constitute a significant section of

<http://www.dickens2012.org/event/charles-dickens-film-locations-london-walk> [accessed 1

October 2013]; and 'The Dickens connection' graveyard walks <http://www.dickens2012.org/event/dickens-connection> [accessed 1 October 2013].

${ }^{27}$ See 'Dickens: Dark London', Museum of London <http://www.museumoflondon.org.uk/Resources/app/Dickens_webpage/index.html > [accessed 1 October 2013]. Interactive maps include the 'Celebrating Dickens' mobile app produced by the University of Warwick <http://www.warwick.ac.uk/dickens > [accessed 1 October 2013].

28 'Dickens and London', British Council <http://www.teachingenglish.org.uk/dickens/dickens$\underline{\text { london> }}$ [accessed 1 October 2013].

${ }^{29}$ Nicola Watson, 'Introduction' in Literary Tourism and Nineteenth-Century Culture, ed. by Nicola Watson (Basingstoke: Palgrave Macmillan, 2009), pp. 1-12 (p. 2). 
the heritage industry. ${ }^{30}$ Dickens's texts invite such practices, rich as they are with locatable details of literary places, and because of the ways in which they manufacture what Juliet John terms a 'heritage aesthetic', commodifying an evocative and definable idea of 'Victorian London' that creates a conflated concept of 'Dickensian-Victorian-London' that has become 'embedded in the British cultural consciousness and in the image of England abroad,' both a source of intranational identity and a national cultural export. ${ }^{31}$

The recourse to place was evident at the time of the centenary of Dickens's birth: as Karen Laird discusses, the film adaptation of David Copperfield produced in 1913 emphasised its ties to the English landscape, creating 'a timely form of virtual literary tourism for an international audience. ${ }^{32}$ One hundred years later, the marketability of locating Dickens in London was much more stringently capitalised on, not least because the broader ongoing popularity of heritage tourism intersects with the current surge of interest in neo-Victoriana in fiction, film and $\mathrm{TV} \cdot{ }^{33}$ Furthermore, a key appeal of heritage and literary tourism is the

\footnotetext{
${ }^{30}$ Nicola Watson, The Literary Tourist (Basingstoke: Palgrave Macmillan, 2006), pp. 10, 172-5.

${ }^{31}$ Juliet John, Dickens and Mass Culture (Oxford: Oxford University Press, 2011), pp. 267-8.

${ }^{32}$ Karen Laird, 'The Posthumous Dickens: Commemorative Adaptations, 1870-2012,' NeoVictorian Studies 5.2 (2012), pp. 12-34 (pp. 20-21).

${ }^{33}$ Literary and cultural engagement with the Victorians can be traced throughout the nineteenth century but the last twenty years have seen a rapid growth in the genre of neo-Victorian fiction, amidst what Louisa Hadley identifies as 'a wider cultural fascination with the Victorians' that spans across TV and film adaptations, heritage culture and political discourse; Louisa Hadley, Neo-Victorian Fiction and Historical Narrative: The Victorians and Us (Basingstoke: Palgrave Macmillan, 2010).
} 
experience of feeling an affiliation with the past: heritage involves 'an emotional attitude to the past' and an 'almost spiritual investment' in the value of places, which offer 'a sense of organic and emotional connection to our ancestors, a sense of roots and of belonging, ${ }^{34}$ Quoting one literary tourist from 1910, Watson reiterates the point that the association is not just a nearness to the descriptions found in Dickens's writing but the feeling of 'treading in Dickens's footsteps': 'It isn't so much because Dickens has described these places [...] It's because I know he went over every inch of the ground himself. And that being so, when I see these places, they seem to bring me near him. ${ }^{35}$

In a year that placed particular emphasis on the interconnections of life and literature, it was fitting that the value of 'treading in Dickens's footsteps' should become prominent. Indeed, it is notable that in the discourses surrounding 2012 activities a particular emphasis was placed on experiencing Dickens's London, not simply asserting the importance of London in Dickens's works but offering up location itself as a means of accessing and understanding Dickensian places today. Interestingly, this was the case both in place-specific activities (walking tours, museums) and in forms of new media (maps, apps and podcasts) that, despite their global reach, frequently focused upon the association between Dickens and London as a core context. 'Dickens and London' thus constituted an intra-national and globally exported form of understanding Dickens, but always returned to the importance of London as the centre-point. These experiences were not so much about 'treading in the footsteps' of Dickens as a means of seeking individual emotional connectivity with the author himself: instead it was place, and particularly London, that became privileged as a means of authenticating the locality of the

\footnotetext{
${ }^{34}$ John, Dickens and Mass Culture, p. 253.

${ }^{35}$ Quoted in Watson, The Literary Tourist, p. 174.
} 
written word. Laird writes of the 1913 David Copperfield that its recourse to the English landscape served to 'crystalliz[e] the writer's reputation as a national treasure' ${ }^{36}$ and created a claim that, Joss Marsh adds, 'only a British [film] company could make'. ${ }^{37}$ A similar claim might be made about 2012 literary tourism: in a globally accessible touristic landscape, the value of national place as the site of access was repeatedly reiterated.

The various formulations of 'Dickens and London' constituted an unofficial history that similarly worked to co-opt Dickens as firmly situated within the nation. Literary tourism has its roots in cultural nationalism: the rise of the practice in the nineteenth century was coterminous with the rise of cultural nationalism and, as Watson writes, 'the emerging national literary canon [was] seized upon in order to effect a sort of interiorised national mapping' ${ }^{38}$ The literary tourisms of 2012 effected a similar form of 'national mapping'. In a city marked by Union Jack flags, images of the Royal Family and Olympic Celebrations, walking 'Dickens's London' in 2012 was implicitly walking Dickens in Britain: walking a route that confirmed Dickens's place within, and contribution to, the national narrative of the city. If the city is a 'tourist stage', as Susan Bennett writes, then the tourists are its players, performing and thus mapping out the relationship between place, nation and author. ${ }^{39}$ If 2012 was a year that performed 'the simultaneous feat of returning us to the Victorian past through Dickens's bicentenary and of propelling us into a very modern twenty-first century with the London Olympics' ${ }^{40}$ then touristic

\footnotetext{
${ }^{36}$ Laird, 'The Posthumous Dickens', p. 20.

${ }^{37}$ Joss Marsh quoted in Laird, 'The Posthumous Dickens', p. 20.

${ }^{38}$ Watson, The Literary Tourist, p. 14.

${ }^{39}$ Bennett, 'The City as Tourist Stage', p. 76.

${ }^{40}$ Boyce and Rousselot, 'The Other Dickens', p. 2.
} 
traversals of Dickens's London provided a site where this apparent dichotomy was negotiated, inscribing the (national) past as part of the contemporary narrative of the city. ${ }^{41}$

Yet this national narrative - privileging London's right to Dickens and suggesting that the essence of understanding his works lies in experiencing his London, in grounding his works within their national origins - was seemingly at odds with the broader discourses of Dickens 2012 as an international celebration. The global reworkings of 'Dickens and London' via digital technologies insisted on (national) place as a requisite to accessing Dickens wherever one was in the world, implicitly confirming Dickens as a national cultural export. At the same time, many of the forms through which these walks and tours were presented - podcasts and apps, online media - meant that the idea of Dickens's London could be anywhere, anytime. They invoked but did not necessitate the requirement that one be in Dickens's London oneself, all existing primarily in the non-space of the internet and entirely portable in their forms. Whilst connected to a discourse of 'Dickens's London' residing in the emotional, direct experience of place, these modes created 'Dickens's London' as something portable, dis-placed and detachable from the sites themselves, something to be experienced anywhere/nowhere. This both indicated the persistent attraction of privileging places as sites of meaning and highlighted the intrinsic instability of spatial centres, drawing attention to the notion of 'Dickens's London' as a cultural construct that can be transported from London itself to new sites of meaning.

Further indicative of these impulses, a number of global refractions of Dickens in 2012 took the idea of 'local Dickens' into new national contexts. The British Council's 'Sketches by

\footnotetext{
${ }^{41}$ The British Library's 'Writing Britain: Wastelands to Wonderlands' exhibition in summer 2012 further articulated these connections between nation, authors and place: see <http://www.bl.uk/whatson/exhibitions/writingbritain > [accessed 1 October 2013].
} 
Boz; Sketching the City' and 'The Uncommercial Traveller' projects took Dickensian modes of urban observation and literary tourism to the streets of cities including Karachi, Beijing, Shanghai, Buenos Aires and New York. ${ }^{42}$ In these projects, cities around the world became contact zones that generated new versions of 'local Dickens' via the reworking of Dickensian modes of representing locality. These projects offered new perspectives on the idea of locality and nation, encouraging us to be attentive to the ways in which locality interacts with and can be detached from national narratives, and the ways in which author celebrations are experienced in different national contexts - something that became more apparent in the World Shakespeare Festival.

\section{Encountering London in the Globe to Globe Festival}

One production in the WSF explicitly confronted the meeting of local/global experiences in an act of staged tourism that visited and mark(et)ed a site of cultural significance. At the opening of Two Gents Productions' Vakomana Vaviri Ve Zimbabwe (The Two Gentlemen of Verona), one of the Globe to Globe productions during the festival year, the empty silence of the Globe stage was disturbed by a trapdoor being pushed open. A head appeared, looked around nervously, then retreated. A moment later, the trapdoor re-opened with a crash, silencing the audience, and two Zimbabwean men wearing Elizabethan costume climbed through it and onto the stage, looking

42 'Sketching the City', British Council <http://literature.britishcouncil.org/projects/2011/dickens-2012/sketches-by-boz-sketching-thecity> [accessed 1 October 2013]; 'The Uncommercial Traveller’, British Council <http://literature.britishcouncil.org/projects/2011/dickens-2012/punchdrunk-the-uncommercialtraveller> [accessed 1 October 2013]. 
about in wonder and carrying a huge travelling trunk. Denton Chikura and Tonderai Munyevu then proceeded to a prologue, delivered in English and translated live into Shona, beginning 'Two gentlemen, both alike in friendship'.

The complexities of this moment of staged tourism, 'blown temporarily onto the Thames Bankside', run deeply. ${ }^{43}$ The two African men arriving on the Globe stage with travelling gear foreshadowed the moment in the 'Isles of Wonder' Olympic Opening Ceremony that conflated the Windrush with the Industrial Revolution (one of the few moments of the Ceremony in which the colour-blind casting policy was ignored), and mirrored it in costuming the arrivals in the perceived uniform of the destination: suits for the West Indian arrivals to London, doublet and hose for arrival at the Globe. This was deliberately mischievous, however. The Globe itself is a representation of an Elizabethan theatre, the majority of whose visitors are dressed in twenty-first century clothes. The 'irredeemably contemporary' audience, in Paul Prescott's terms, was acknowledged by the performance of arrival by the actors: in a reversal of the Globe's usual dynamic which invites a visiting audience to step back into the world created by the playhouse, here we saw Elizabethan actors arriving into a contemporary world for which they were clearly inappropriately dressed. ${ }^{44}$ As the actors broke open their trunk and began putting on more transhistorical clothes to represent their various characters, the initial acknowledgement of the

${ }^{43}$ Penelope Woods, 'The Two Gentlemen of Verona', in A Year of Shakespeare, pp. 222-6 (p. 224).

${ }^{44}$ Paul Prescott, 'Inheriting the Globe: The Reception of Shakespearean Space and Audience in Contemporary Reviewing', in A Companion to Shakespeare and Performance, ed. by Barbara Hodgdon and W.B. Worthen (Malden: Wiley-Blackwell, 2005), pp. 359-75 (p. 362). 
Elizabethan was forgotten, replaced by a performance style reliant on Shona storytelling and a form of gestus that contrasted with the Globe's usual house style.

The company's introduction into the space was greeted with laughter, suggesting the perceived incongruity of two African men in Elizabethan costume tiptoeing onto the Globe stage, unsure of whether or not they were meeting the correct conventions. In some ways, this was a deliberate strategy of Two Gents Productions, which is a British-based company (see Colette Gordon's chapter in this volume). This performance was the first time the play, which had been touring for several years, had been translated into Shona from its usual English text. ${ }^{45}$ In explicitly drawing attention to the conventions of the Globe space, they then enacted an imposition of a Zimbabwean language and performance culture, evoking and then rejecting Elizabethan performance traditions. Yet it spoke to the power structures of a space of cultural tourism, making explicit the status of the company as 'visitors' to the 'home' Shakespeare audience, while also drawing attention to the playing of an act of tourism.

Returning to Juliet John's notion of the 'almost spiritual investment' in the value of places, which offer 'a sense of organic and emotional connection to our ancestors, a sense of roots and of belonging', we can use the example of Vakomana Vaviri ve Zimbabwe as paradigmatic of the inversion of cultural tourism in the World Shakespeare Festival. While the Year of Shakespeare website features a map indicating the 'home' locations of the productions featured throughout the year, the global scale elides the performance map that would be much more narrowly focused (see Fig. 3). Performances during the Festival took place almost entirely

\footnotetext{
${ }^{45}$ See Sonia Massai, 'Two Gentlemen of Verona For/By Zimbabwean Diasporic Communities' in Shakespeare Beyond English, ed. by Susan Bennett and Christie Carson (Cambridge: Cambridge University Press, 2013), pp. 157-60 (p. 158).
} 
in London and Stratford-upon-Avon, sites of local significance connected to authorial biography and geographical footprint, with scattered other locations throughout the United Kingdom showcasing a handful of other productions. ${ }^{46}$ The literary tourism that characterised Dickens 2012 involved the mobilisation of audiences, inviting app users and visitors to experience the spaces of Dickens's London. For the World Shakespeare Festival, it was performers who were mobilised, brought in from around the globe to share London stages.

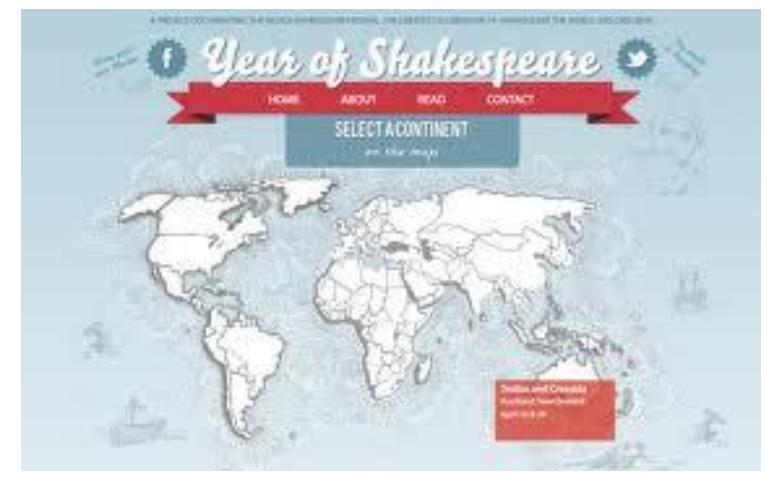

Fig $\mathrm{x}$ : The Year of Shakespeare website with its global map indicating the continent and country of origin of every WSF production.

The slippage between local and national identities thus becomes more obvious in the place of performance, as the BBC Four documentary Shakespeare from Kabul (broadcast 21 July 2012) made clear. ${ }^{47}$ Following the journey of the Afghan production of The Comedy of Errors from initial inception to final performances at the Globe to Globe Festival, the documentary concentrates on the local contexts of production, the political and social pressures on the company, the struggles to find appropriate modes of rehearsal, and the fears of ongoing stigmatisation. London, spoken of in reverential terms, is a distant goal. As the documentary

\footnotetext{
${ }^{46}$ See Hansen and Smialkowska, below.

${ }^{47}$ Shakespeare from Kabul, dir. Harriet Shawcross. BBC Four, 21 July 2012.
} 
moves to London, revealed in panoramic aerial shots capturing the glistening Thames, the sunlit landmarks and the resplendent Globe, the focus of the documentary moves to the wonder of the actors visiting for the first time, the joy of reception in Shakespeare's home theatre and the role of London in consolidating personal achievements.

The significance of this in an Olympic year cannot be lost: as with the sporting festival, personal achievement can only be fully realised on a London stage. Yet even if this is not the documentary's intention, it reveals a hierarchy of experienced place. London is both the site of original production of Shakespeare's texts and the place of the performed 2012 Festival, and it is within this site that the productions devised, rehearsed and perfected overseas were received. Against the shared backdrop of the facsimile Elizabethan stage, ghosts of Africa, Asia, Europe, America and Australasia were fleetingly seen. The Globe as the Shakespearean heritage site was the fixed point, and several companies made this explicit by kissing the stage or acknowledging their delight in arriving for their holiday, often bringing their camera-phones onto the stage during the curtain call to enact an explicit act of London tourism as soon as out of character.

The more complex foregrounding of the tourist experience by Two Gents Productions was suggestive of anxieties over what it means for Shakespeare to be 'the world's dramatist'. The ownership and appropriation of Dickens in places all around the world, appropriating modes of city-writing for locations other than London, saw Dickens 2012 spread internationally. The World Shakespeare Festival, however, instead seemed to offer Shakespeare bound to his historical places of operation, a home member of Team GB. While many of the productions of the Festival had been and would continue to be experienced around the world, the role of the Festival was to concentrate these interpretations of Shakespeare in a relatively confined 
geographical area - to borrow Stephen Purcell's reading of the Globe to Globe Festival, in some cases within a concentric circle even smaller than E20. ${ }^{48}$

The principle of the Globe stage has always been to foreground the fictional production of space, from the first time the Chorus to Henry $V$ acknowledged the insufficiency of place and invited its audience to engage in the production of a space of European conflict. The World Shakespeare Festival continued this ethos of delocalisation even as it hosted productions that had begun locally in their places of origin. At Stratford-upon-Avon, the Courtyard and Royal Shakespeare Theatres played host to representations of 'India' (Iqbal Khan's Much Ado about Nothing) and 'Africa' (Gregory Doran's Julius Caesar) populated by companies of BritishIndian and British-African actors. Both productions went to great lengths to create something of the atmosphere of those locales - Caesar through onstage music and a recruited cast of extras who joined the stage for crowd scenes, Much Ado through extensive pre-show entertainments, inviting audience members on stage for the wedding and so on (these productions are discussed in detail in Purcell and Gordon in this volume). These strategies in turn transformed theatregoers into tourists, most noticeably in Much Ado as a shady man in sunglasses accosted audience members before the play started, offering them cut-price rates in his nearby hotel. In both productions, the divorce from the place of representation was made complete, ensuring that the relationship between audience and fictional world was always considered from the tourist perspective, the temporary and detached visitor to a socially constructed imaginative space.

${ }^{48}$ Steve Purcell, 'Circles, Centres, and the Globe to Globe Festival', Year of Shakespeare, 22 June 2012, <http://bloggingshakespeare.com/year-of-shakespeare-circles-centres-and-the-globeto-globe-festival > [accessed 1 October 2013]. 
At the Globe, the site-specificity of the place of reception conflated the permanent significance of the faux-Elizabethan tiring house and pillars with the fluidity of a stage that allows for complete geographical and temporal variation of imagined place. To borrow the title of the British Museum's exhibition curated as part of the Festival, the Globe itself was involved in 'Staging the world'. The fixed place of the stage, however, makes the world itself mobile. If the appropriations of Dickens's London were delocalised in order to be staged any/everywhere, the international appropriations of Shakespeare's works were similarly detached from their local contexts in order to be performed in London, picking up on the ideas of embodied mobility that characterise the Dickens walking tours. Places of personal origin are collapsed in favour of a shared experientiality at the point of reception, participating in the production of an Elizabethan literary tourism even when the words being spoken are not Shakespeare's. Both Festivals prioritised the relatively homogeneous site of encounter over the broader networks of cultural heritage staged within.

\section{London calling}

Both Festivals therefore played a prominent role in articulating London as the centre-point of the production of national capital, taking advantage of the profiles of the city's major writers as well as London itself as tourist destination to create a located literary tourism. Despite attempts to involve the whole country in the London Olympic Games, the branding of the Games repeatedly suggested otherwise, that 2012 was not so much Britain's year but the capital's: 'London 2012' became a byword for this consolidation of the capital's pre-eminence on the national, and global, stage. London 2012 involved a performance of London to the world and to itself, in a manner not dissimilar to that in which it once welcomed the newly crowned King James I, formerly James 
VI of Scotland. Thomas Dekker, Stephen Harrison, Ben Jonson and Thomas Middleton's Magnificent Entertainment of 1604 created an event in which 'the civic community, headed by its chief officers, became the King's host, as if London was a great country house and the mayor its lord. ${ }^{49}$ As Janette Dillon remarks of this extraordinarily opulent event,

In the very act of gracious deferral to the king, the city seeks to present its own best face not only to the king and queen and the royal court but also to London citizens themselves, to foreigners living and working in London and to visitors to London for the occasion. There is no clear distinction to be made between spectators and participants. ${ }^{50}$

The city performs the role of host, and simultaneously re-performs this spectacle for the benefit of its constituent members. Likewise in 2012, everyone in London, native or visitor, became an actor on the city stage.

For Dickens, London was "the "magic lantern" which filled his imagination with the glimpse of strange dramas and sudden spectacles'. ${ }^{51}$ The 'strangeness' of the city stage is most apparent in the self-awareness of mobile tourism, whether inviting walkers to experience the city streets through the lens of a Dickensian topography or staging the arrival of Shakespearean

${ }^{49}$ R. Malcolm Smuts, 'The Whole Royal and Magnificent Entertainment', in Thomas Middleton: Collected Works, ed. by Gary Taylor and John Lavagnino (Oxford: Oxford UP, 2007), pp. 21923 (p. 220).

${ }^{50}$ Janette Dillon, Theatre, Court and City, 1959-1610: Drama and Social Space in London (Cambridge: Cambridge UP, 2000), p. 140.

${ }^{51}$ Quoted in Peter Ackroyd, London: The Biography (London: Chatto \& Windus, 2000), p. 152. 
tourists on the city's literal stages. In all cases, however, the city itself creates the conditions for the performances of its actors. Even as James's entry collapsed the division between spectators and participants and 'Dickens's London' turned the walking tourist into a participant in the city environment, so too did the Shakespeare and Dickens Festivals turn the populace of London into actors by insisting on the role of London itself as a stage for the world.

The tension between London and the rest of Great Britain and Northern Ireland (the full name of Team GB, reminding us of the abbreviation's elision of a significant constituent member) was felt deeply during the relay of the Olympic Torch around the country, taking in literary tourist destinations such as Stratford-upon-Avon, where it was photographed in front of the Birthplace, and Higham, where the Torch changed hands in front of Gad's Hill Place, the site of Falstaff's humiliation and Dickens's writing of Great Expectations and A Tale of Two Cities. Philip Hensher, writing in the Guardian, traced problems surrounding the torch back to the 2008 Games:

$[F]$ our years ago the Chinese sent the flame abroad, followed by security staff whose job it was to beat up protesters against the Chinese human rights record. In the wake of some appropriately violent scenes in London, the then Chinese ambassador distinguished herself by quoting a correspondent who had said they could not believe this was the land that created Shakespeare and Dickens. What Dickens would have thought of massively expensive and over-policed festivals of minor sport, not to mention what the Chinese 
government did to its blind dissidents, might not have been quite what the ambassador believed. $^{52}$

The show of unity offered by the Olympic Flame was undercut at points of protest during both the 2008 and 2012 relays, and it is interesting to note that Dickens and Shakespeare were evoked as representative of unified, peaceful, national conservatism. Yet as Hensher goes on to say, 'on the occasion of the Bearing of the Torch Through Exeter, I've stayed safely in south London, so I can't tell you what it was like at all.' Once the flame had arrived in London, of course, and the 'Isles of Wonder' Opening Ceremony had offered a united, neo-Victorian and Shakespearequoting vision of the country, far less dissent was heard. As David Beckham's speedboat docked in E20 and the torch was passed to Sir Steve Redgrave to be carried into the stadium, the nationbuilding exercises that led up to the sporting competition were united. The implications of being 'safely in London', away from the problems posed by a greater nation that may not always be in line with the cultural centre, are unpacked in Adam Hansen and Monika Smialkowska's following chapter in this volume, but despite gestures towards the cultural activity happening around the country, all roads ultimately led to London E20, at the heart of which were situated Shakespeare and Dickens.

\footnotetext{
${ }^{52}$ Philip Hensher, 'Olympic Torch Route, Day 3: A Conscientious Objector Writes', Guardian, 21 May 2012 <http://www.guardian.co.uk/sport/2012/may/21/olympic-torch-route-day-3>
} [accessed 1 October 2013]. 